\title{
REVIEW
}

Open Access

\section{A critical review of self-care for sleep disturbances: prevalence, profile, motivation, perceived effectiveness and medical provider communication}

\author{
Sophie Meredith ${ }^{1,2^{*}}$, Jane Frawley ${ }^{1}$, David Sibbritt ${ }^{1}$ and Jon Adams ${ }^{1}$
}

\begin{abstract}
Objective: This study aims to undertake the first critical review of self-care use among adults with sleep disturbances by focusing on the prevalence of self-care-the self-determined and self-administered use of products or practices - by adults with sleep disturbances.

Methods: A comprehensive search of 2006-2016 international literature in CINAHL, AMED, Medline and EMBASE databases was conducted. The search was confined to empirical research findings regarding sleep disturbances - as indicated by a validated sleep scale/index or clinician diagnosis.

Results: Of the 21 articles included in this review, only three reported on sleep disturbances other than insomnia disorder (ID) or insomnia symptoms (IS). Overall, a high prevalence of self-care use is reported among adults with sleep disturbances, particularly for ID and IS. Self-care products and practices are more likely to be used by adults with sleep disturbances, than those without sleep disturbances. Commonly used self-care products and practices include OTC hypnotics, antihistamines, diphenhydramine products, diet, exercise, painkillers, herbal medicines, vitamins, minerals and dietary supplements, yoga, tai chi, Qigong, meditation, exercise and relaxation.

Conclusions: Many adults with sleep disturbances-particularly ID or IS-frequently use self-care products and practices. Self-care products are also used concomitantly with conventional prescription medications without disclosure to medical professionals. The current literature is of varied methodological caliber, frequently relies on small sample sizes and low-quality data collection therefore further rigorous health services research is required. There is an especial paucity of data regarding self-care for sleep disturbances such as restless legs syndrome and obstructive sleep apnea. Healthcare providers may find it beneficial to actively ask patients about their use of self-care for sleep disturbances to help avoid harmful drug-drug or drug-herb interactions.
\end{abstract}

Keywords: Restless legs syndrome, Self care, Sleep apnea syndromes, Sleep initiation and maintenance disorders, Complementary therapies, Patient-centered care, Critical review

\footnotetext{
* Correspondence: sophielouise.meredith@student.uts.edu.au

'University of Technology, Faculty of Health, Sydney (UTS), NSW, Australia

${ }^{2}$ Charles Sturt University, Faculty of Science, Bathurst, NSW, Australia
}

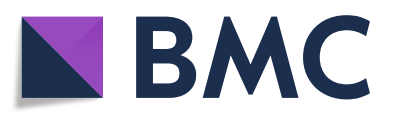

(c) The Author(s). 2020 Open Access This article is distributed under the terms of the Creative Commons Attribution 4.0 International License (http://creativecommons.org/licenses/by/4.0/), which permits unrestricted use, distribution, and reproduction in any medium, provided you give appropriate credit to the original author(s) and the source, provide a link to the Creative Commons license, and indicate if changes were made. The Creative Commons Public Domain Dedication waiver (http://creativecommons.org/publicdomain/zero/1.0/) applies to the data made available in this article, unless otherwise stated. 


\section{Introduction}

Sleep disturbances such as insomnia symptoms (IS) - characterized by difficulty in initiating or maintaining sleep (Morin et al. 2006; Ohayon 2001) — can affect up to a third of the population internationally (Léger et al. 2007; Ohayon 2002) and up to 56\% in the USA (Léger et al. 2007). Older people and women are particularly susceptible, the intersection of these characteristics causing prevalence estimates of IS to rise to between 49 and 72\% (Byles et al. 2005; Meredith et al. 2017; Meredith et al. 2019) within nationally representative cohorts of older women in Australia. Distinct from IS, insomnia disorder (ID), as well as including difficulties initiating or maintaining sleep, is also characterized by dissatisfaction with sleep quality or duration and with significant distress and impairments of daytime functioning (Morin et al. 2015). Compared with IS alone, ID is known to affect a significant but reduced proportion of the population of between 3.9-22.1\% (Morin et al. 2015). Other common sleep disturbances such as restless legs syndrome (RLS) and sleep disordered breathing (SDB) have been reported to affect up to $29 \%$ (Innes et al. 2011) and $38 \%$ (Senaratna et al. 2017) of the population respectively and represent a major public health issue. SDB and RLS also affect older populations disproportionately (Innes et al. 2011; Senaratna et al. 2017; Leger et al. 2012).

Varying definitions of self-care are rapidly emerging, in tandem with a trend toward patient-centered health care and an increase in chronic over acute, conditions (Mun et al. 2016). Here, we define self-care as the self-determined and self-administered use of products or practices for addressing health problems and/or maintaining health practiced by individuals without instruction from healthcare professionals in line with established research definitions (Mun et al. 2016; Adams et al. 2018). Both complementary and alternative medicine (CAM) self-care (e.g. taking herbs or practicing meditation) and conventional self-care (e.g. exercise or over-the-counter (OTC) drugs such as acetaminophen) have become increasingly popular in Western societies (Frass et al. 2012; Qato et al. 2008).

Frontline conventional medical treatments for sleep disturbances are typically prescription medications including benzodiazepines, zolpidem and zopiclone for insomnia, and dopaminergic agents for restless legs syndrome (RLS), all of which can have harmful side effects (Wang et al. 2014; Leach and Page 2015; Gamaldo and Earley 2006). Frontline solutions for other sleep disturbances such as obstructive sleep apnea (OSA), which include continuous positive airway pressure (CPAP) machines and surgery, have also presented problems including accessibility, adherence, disruption of bed-partners' sleep (Knauert et al. 2015; Weaver et al. 2003), high morbidity, and ambivalent results in the case of surgical treatment (Knauert et al. 2015).
There is evidence to suggest many people with sleep disturbances avoid seeking professional medical help partly due to aforementioned concerns, and as a way for people to maintain a feeling of control over their health (Knauert et al. 2015; Venn et al. 2013). Adults with sleep disturbances sometimes consider self-care products (such as natural herbs or OTC pharmaceuticals such as Diphenhydramine or Doxylamine) effective alternatives to seeking professional medical help (Meredith et al. 2017; Abraham et al. 2017) as well as self-care practices including relaxation techniques, yoga and tai chi (Bertisch et al. 2009).

Popular self-care products and practices for sleep disturbances include, drinking chamomile tea or a hot milk before sleep, taking OTC medications such as antihistamines, herbal medicines, Chinese medicines, melatonin (as reported in countries in which it is considered an OTC), engaging in meditation and relaxation techniques (Meredith et al. 2017; Bertisch et al. 2009; Boon et al. 2013; Cherniack et al. 2008; Fouladbakhsh and Stommel 2010; Frawley et al. 2015; Furihata et al. 2011; Liu et al. 2016; Moore et al. 2011; Pearson et al. 2006; Tsai et al. 2008; Williams et al. 2014).

Although in some cases these options are promoted as safer options compared to prescription treatments for certain sleep disturbances, with reduced or no side effects (Fernández-San-Martín et al. 2010), there is limited evidence of efficacy and safety, with specific concern about OTC products taken without medical advice (Meredith et al. 2017; Abraham et al. 2017) particularly in the context of undisclosed concurrent use with medical drugs (Leach and Page 2015). Nonetheless, research suggests that self-care products and practices are utilized more frequently than prescription medications by people with sleep disturbances (Morin et al. 2006; Sivertsen et al. 2009; Sánchez-Ortuño et al. 2009; Worthington and Melia 2006).

Due to the high use of self-care products for sleep disturbances, confusion over best treatments for individual sleep disturbances, absence of information regarding adults' treatment preferences and safety concerns about overuse and concurrent use with pharmaceutical medications, a synthesis of this information is timely.

Empirical research indicating the prevalence of use of health services-including self-care for the treatment of sleep disturbances-has become increasingly available over the last 10 years (Meredith et al. 2017; Sandberg et al. 2014). Whilst there is a significant body of research focusing exclusively on the heightened use of conventional medical services for people with sleep disturbances (Blay et al. 2008; Moloney et al. 2011; Novak et al. 2004; Sarsour et al. 2011; Kaufmann et al. 2013; Bin et al. 2012), prevalence information on the use of self-care, including OTC medicine use is scattered with 
articles focusing mostly on just one or two aspects of use (e.g. herbs or OTC medications). A critical synthesis of health strategies in the management of sleep disturbances has not been undertaken to date. In response to this gap, this paper reports findings from the first review of self-care use among individuals with sleep disturbances. As well as helping identify patterns of use of self-care products (such as OTCs) it will also investigate concurrent use of self-care products with prescription medicine which, without medical advice, may be associated with safety issues (Leach and Page 2015).

This review, in also seeking to explore self-care practices generally considered safe (such as yoga and relaxation techniques) also aims to identify both potentially risky and effective self-care options for various sleep disturbances that may currently be being initiated beyond the purview of medical practitioners. As what is considered 'risky' may depend upon the sleep disturbance itself, different categories (ID and IS, RLS, and SDB) will be discussed separately.

\section{Participants and methods Search design}

CINAHL, AMED, the Medline and EMBASE databases were searched for articles published from 2006 to 2016 that used key words and phrases relating to sleep disturbances AND key words and phrases related to self-care options. The CINAHL, Medline and EMBASE are three of the most wide-ranging and utilized databases in medical and health scholarship. We supplemented this search with use of the AMED database, known as an authoritative resource for scholarship in complementary and alternative medicine. The search was limited to peer-reviewed articles published in the English language between 2006 and 2016.

Self-care was defined-in line with established research definitions (Mun et al. 2016; Adams et al. 2018) - as the self-determined and self-administered use of products or practices for addressing health problems and/or maintaining health practiced by individuals without instruction from healthcare professionals. Details of the search criteria can be found in the Additional file 1 .

Sleep disturbances represent a broad spectrum of complaints with different treatment options available. Diagnostic criteria and definitions for individual sleep disturbances and their symptoms are varied and numerous. Consistent nosology with sufficient clarity of definition, has thus far remained elusive (Morin and Espie 2011). Research also suggests that the absence of clear scales and diagnostic instruments for the identification of sleep disturbances can cause a heterogeneity of results that are sometimes difficult to rely upon (Ohayon et al. 2012; Henry et al. 2016). Consequently, to enable meaningful comparison and collation of results, we only included articles where a validated sleep scale or index was used, or where the condition was diagnosed by a clinician.

Studies were considered to be assessing ID if they used a validated tool/measure widely used for the validation of insomnia such as the Insomnia Severity Index (ISI), the APA Diagnostic and Statistical Manual of Mental Disorders (DSM-IV), the Brief Insomnia Questionnaire (BIQ) and the International Classification of Sleep Disorders (ICSD) or a physician diagnosis. Articles were also included with reported IS if the article indicated that participants had symptoms of insomnia-such as frequent nocturnal awakenings, the presence of a long sleep latency or extended periods of wakefulness during the period of sleep (Sateia et al. 2000) as indicated by a validated sleep scale used to measure IS such as the medical outcomes study sleep scale (MOS-SS) and the Pittsburgh sleep quality index (PSQI). Further, in this review, the category 'ID and IS' include some articles which report 'poor sleep' and sleep-wake disturbance (SWD) because the Pittsburgh Sleep Quality Index (PSQI) (used for studies reporting poor sleep) and the Insomnia Severity Index (ISI) (used for the study reporting on SWD) have been validated as measures for ID and IS (Backhaus et al. 2002; Bastien et al. 2001) therefore people with poor sleep and SWD as defined using these tools will likely be seeking treatments for symptoms related to insomnia. Similarly, other sleep disturbances were included in the review if they employed rigorous tools for screening such as physician diagnosis, widely accepted diagnostic criteria and validated indexes such as the apnea-hypopnea index (AHI) and the respiratory disturbance index (RDI). As there is currently no synthesis of self-care literature for any type of sleep disturbance or disorder. This review of the international literature is thus intended as a starting point and a platform for further research concerning self-care treatments for disturbed sleep by adults.

For a detailed overview of the search design and criteria see Additional file 1.

\section{Search outcomes}

The initial search identified 7990 articles after duplicates were removed. Of these, 21 articles from 19 empirical studies (two projects were reported by more than one article) met inclusion criteria and were included in the review. A summary of findings from included papers is reported in Table 1:

\section{Quality appraisal}

A quality scoring system was utilized in order to assess the quality of the final papers selected for review (Table 2). The scoring system employed an established analytical tool used in numerous health reviews (Bishop et al. 2011; Fejer et al. 2006; Peng et al. 2014; Moore 
Table 1 Research-based studies of self-care for adults for sleep disturbances, 2006-2016

\begin{tabular}{|c|c|c|c|c|c|c|c|}
\hline & Country & $\begin{array}{l}\text { Sleep Assessment Tool/ } \\
\text { s }\end{array}$ & $\begin{array}{l}\text { Condition/ } \\
\text { profile focus }\end{array}$ & $\begin{array}{l}\text { Popular self-care prod- } \\
\text { ucts and practices }\end{array}$ & Method & $\begin{array}{l}\text { Sample/predictors of } \\
\text { use }\end{array}$ & Themes \\
\hline $\begin{array}{l}\text { Allen et al. } \\
2008\end{array}$ & USA & $\begin{array}{l}\text { Medical Outcomes } \\
\text { Study (MOS) sleep } \\
\text { questionnaire }\end{array}$ & $\begin{array}{l}\text { Osteoarthritis, } \\
\text { insomnia } \\
\text { symptoms, } \\
\text { insufficient } \\
\text { sleep }\end{array}$ & $\begin{array}{l}\text { Over-the counter } \\
\text { (OTC)) medications } \\
(12 \% \text { people with } \\
\text { osteoarthritis and sleep } \\
\text { disorders) } \\
\text { Herbal medications (1\% } \\
\text { people with } \\
\text { osteoarthritis and sleep } \\
\text { disorders) }\end{array}$ & $\begin{array}{l}\text { Cross-sectional, self- } \\
\text { administered ques- } \\
\text { tionnaire survey }\end{array}$ & $\begin{array}{l}1910 \\
\text { Being female white } \\
\text { American versus female } \\
\text { African American }\end{array}$ & 1 \\
\hline $\begin{array}{l}\text { Andrews } \\
\text { et al. } 2013\end{array}$ & USA & $\begin{array}{l}\text { PSQI, Insomnia Severity } \\
\text { Index (ISI), } \\
\text { Dysfunctional Beliefs } \\
\text { and Attitudes about } \\
\text { Sleep Scale (DBAS) and } \\
\text { Sleep Heart Health } \\
\text { Study (SHHS) Sleep } \\
\text { Habits Questionnaire, } \\
\text { ESS }\end{array}$ & $\begin{array}{l}\text { Heart failure } \\
\text { and Insomnia }\end{array}$ & $\begin{array}{l}\text { St John's wort ( } 9 \% \\
\text { people with insomnia } \\
\text { and stable heart } \\
\text { failure), vitamins/ } \\
\text { mineral supplements } \\
\text { ( } 73 \% \text { with insomnia } \\
\text { and stable heart failure) } \\
\text { OTCs (100\% with } \\
\text { insomnia and stable } \\
\text { heart failure) }\end{array}$ & $\begin{array}{l}\text { Two focus group } \\
\text { sessions and } \\
\text { questionnaires }\end{array}$ & 11 & $\begin{array}{l}1,2,3 \\
4\end{array}$ \\
\hline $\begin{array}{l}\text { Bin et al. } \\
2012\end{array}$ & Australia & $\begin{array}{l}\text { The Assessment of } \\
\text { Quality of Life (AQOL) } \\
\text { instrument, cross- } \\
\text { validated against com- } \\
\text { monly used indicators } \\
\text { of insomnia }\end{array}$ & Insomnia & $\begin{array}{l}\text { Herbs, vitamins and } \\
\text { minerals ( } 20 \% \text { adults } \\
\text { with insomnia vs. 10\% } \\
\text { without insomnia). } \\
\text { No concurrent use stats }\end{array}$ & $\begin{array}{l}\text { Nationally } \\
\text { representative cross- } \\
\text { sectional national sur- } \\
\text { vey using computer- } \\
\text { aided personal } \\
\text { interviews }\end{array}$ & 8841 & 1, \\
\hline $\begin{array}{l}\text { Braley } \\
\text { et al. } 2015\end{array}$ & USA & $\begin{array}{l}\text { ISI, ESS, STOP-BANG } \\
\text { questionnaire (for sleep } \\
\text { apnea), ISI, RLS diagnos- } \\
\text { tic criteria }\end{array}$ & $\begin{array}{l}\text { Insomnia/OSA/ } \\
\text { RLS }\end{array}$ & $\begin{array}{l}\text { OTCs. OTC hypnotic } \\
\text { use frequency NOT } \\
\text { associated with } \\
\text { insomnia or sleep } \\
\text { apnea. People with RLS } \\
\text { versus those without } \\
\text { had a higher } \\
\text { prevalence of } \\
\text { diphenhydramine- } \\
\text { containing products } \\
\text { (40\% versus 18\%, chi- } \\
\text { squared } P=0.0002 \text { ). }\end{array}$ & $\begin{array}{l}\text { Medical records and } \\
\text { self-administered } \\
\text { questionnaires }\end{array}$ & 190 & 1 \\
\hline $\begin{array}{l}\text { Cheung } \\
\text { et al. } 2014\end{array}$ & Australia & $\begin{array}{l}\text { Clinician Diagnosis and } \\
\text { ISI. }\end{array}$ & Insomnia & $\begin{array}{l}\text { Valerian and } \\
\text { supplements }\end{array}$ & $\begin{array}{l}\text { Self-administered } \\
\text { questionnaire and } \\
\text { individual in-depth, } \\
\text { semi-structured } \\
\text { interviews }\end{array}$ & 26 & $2,3,4$ \\
\hline $\begin{array}{l}\text { Daley et } \\
\text { al. } 2009\end{array}$ & Canada & $\begin{array}{l}\text { PSQI, ISI, algorithm } \\
\text { based on APA } \\
\text { Diagnostic and } \\
\text { Statistical Manual of } \\
\text { Mental Disorders (DSM- } \\
\text { IV) and World Health } \\
\text { Organization (WHO) } \\
\text { ICD-10 classification of } \\
\text { mental and behavioral } \\
\text { disorder: diagnostic cri- } \\
\text { teria for research }\end{array}$ & $\begin{array}{l}\text { Insomnia and } \\
\text { insomnia } \\
\text { symptoms }\end{array}$ & $\begin{array}{l}\text { OTC medications ( } 76 \% \\
\text { adults with insomnia } \\
\text { vs. } 62 \% \text { good sleepers) } \\
\text { OTC medications for } \\
\text { insomnia ( } 10 \% \text { adults } \\
\text { with insomnia } \\
\text { syndrome, } 5 \% \text { insomnia } \\
\text { symptoms and } 1 \% \text { of } \\
\text { good sleepers). }\end{array}$ & $\begin{array}{l}\text { Self-administered } \\
\text { questionnaires and } \\
\text { government health- } \\
\text { care databases }\end{array}$ & 953 & 1 \\
\hline $\begin{array}{l}\text { Henry } \\
\text { et al. } 2013\end{array}$ & USA & $\begin{array}{l}\text { Physician confirmed } \\
\text { diagnosis }\end{array}$ & Insomnia & $\begin{array}{l}\text { OTC medications or } \\
\text { dietary supplements } \\
\text { ( } 46 \% \text { adults with } \\
\text { insomnia) } \\
\text { Diet or exercise ( } 25 \% \\
\text { adults with insomnia) } \\
\text { Yoga (13\% adults with } \\
\text { insomnia) } \\
\text { Self-hypnosis (13\% } \\
\text { adults with insomnia) } \\
\text { Relaxation (13\% adults }\end{array}$ & $\begin{array}{l}\text { In-depth semi- } \\
\text { structured interviews }\end{array}$ & 24 & $1,2,3,4$ \\
\hline
\end{tabular}


Table 1 Research-based studies of self-care for adults for sleep disturbances, 2006-2016 (Continued)

\begin{tabular}{|c|c|c|c|c|c|c|c|}
\hline & Country & $\begin{array}{l}\text { Sleep Assessment Tool/ } \\
\text { s }\end{array}$ & $\begin{array}{l}\text { Condition/ } \\
\text { profile focus }\end{array}$ & $\begin{array}{l}\text { Popular self-care prod- } \\
\text { ucts and practices }\end{array}$ & Method & $\begin{array}{l}\text { Sample/predictors of } \\
\text { use }\end{array}$ & Themes \\
\hline & & & & $\begin{array}{l}\text { with insomnia) } \\
\text { Herbal tea or warm } \\
\text { milk ( } 8 \% \text { adults with } \\
\text { insomnia) } \\
\text { Meditation/prayer ( } 8 \% \\
\text { adults with insomnia)* } \\
\text { *all listed above were } \\
\text { taken } \\
\text { contemporaneously } \\
\text { with professional } \\
\text { medical treatment }\end{array}$ & & & \\
\hline $\begin{array}{l}\text { Homsey } \\
\text { and } \\
\text { O'Connell } \\
2012\end{array}$ & USA & PSQI & $\begin{array}{l}\text { Poor sleep/ } \\
\text { insomnia } \\
\text { symptoms }\end{array}$ & $\begin{array}{l}\text { Take antihistamines } \\
(22 \%) \\
\text { Drink liquids at } \\
\text { bedtime (22\%) } \\
\text { Breathe deeply (19\%) } \\
\text { Take melatonin (16\%) } \\
\text { Use guided imagery } \\
(16 \%) \\
\text { Practice Progressive } \\
\text { Muscle Relaxation } \\
\text { (PMR) (16\%) } \\
\text { Take valerian (9\%) } \\
\text { Practice yoga (6\%) } \\
\text { Take Kava Kava (5\%)* } \\
\text { * } 90 \% \text { of sample had } \\
\text { poor sleep/insomnia } \\
\text { symptoms according to } \\
\text { PSQl. 10\% either } \\
\text { subjectively considered } \\
\text { themselves to have } \\
\text { sleep disorders or may } \\
\text { have recovered from } \\
\text { sleep disorders. All } \\
\text { participants reported } \\
\text { using the above } \\
\text { products or practices } \\
\text { for sleep disorders. }\end{array}$ & Web-based survey & $\begin{array}{l}300 \\
\text { Higher income level } \\
\text { (yoga), higher } \\
\text { education attainment } \\
\text { (guided imagery), being } \\
\text { female (valerian and } \\
\text { kava kava and guided } \\
\text { imagery) }\end{array}$ & 1,3 \\
\hline $\begin{array}{l}\text { Krakow et } \\
\text { al. } 2014\end{array}$ & USA & $\begin{array}{l}\text { Physician diagnosis, } \\
\text { International } \\
\text { Classification of Sleep } \\
\text { Disorders and ISI, } \\
\text { apnea-hypopnea index } \\
\text { (AHI), respiratory dis- } \\
\text { turbance index (RDI). }\end{array}$ & $\begin{array}{l}\text { Insomnia } \\
\text { disorder (ranked } \\
\text { as chief concern } \\
\text { for all } \\
\text { participants) }\end{array}$ & $\begin{array}{l}\text { OTC medications ( } 49 \% \\
\text { adults with insomnia } \\
\text { using any OTC sleep } \\
\text { aid and } 37 \% \text { of all } \\
\text { participants for sleep) }\end{array}$ & $\begin{array}{l}\text { Medical Records and } \\
\text { online questionnaire }\end{array}$ & $\begin{array}{l}1210 \\
\text { Being female, } \\
\text { higher education } \\
\text { attainment, } \\
\text { being white (vs. } \\
\text { Hispanic) }\end{array}$ & 1 \\
\hline $\begin{array}{l}\text { Liu et al. } \\
2016\end{array}$ & $\begin{array}{l}\text { Hong } \\
\text { Kong }\end{array}$ & $\begin{array}{l}\text { DSM-IV and ICD-10, ISI } \\
\text { and ESS }\end{array}$ & Insomnia & $\begin{array}{l}\text { OTC medications (16\% } \\
\text { adults with insomnia) }\end{array}$ & $\begin{array}{l}\text { Cross-sectional } \\
\text { mailed questionnaire }\end{array}$ & 2231 & 1 \\
\hline $\begin{array}{l}\text { Matthews } \\
\text { et al. } 2016\end{array}$ & USA & $|S|$ & $\begin{array}{l}\text { Traumatic brain } \\
\text { injury (TBI), } \\
\text { sleep wake } \\
\text { disturbance } \\
\text { (SWD) using ISI } \\
\text { (insomnia } \\
\text { symptoms) as } \\
\text { measure }\end{array}$ & $\begin{array}{l}\text { Meditation, natural } \\
\text { medications/sleep aids, } \\
\text { breathing, dietary } \\
\text { supplements, } \\
\text { melatonin and exercise } \\
\text { (prevalence rates not } \\
\text { reported). }\end{array}$ & $\begin{array}{l}\text { Semi-structured } \\
\text { interviews }\end{array}$ & 19 & $2,3,4$ \\
\hline $\begin{array}{l}\text { Morin } \\
\text { et al. } 2006\end{array}$ & Canada & $\begin{array}{l}\text { Algorithm based on } \\
\text { APA Diagnostic and } \\
\text { Statistical Manual of } \\
\text { Mental Disorders (DSM- } \\
\text { IV and World Health } \\
\text { Organization (WHO) } \\
\text { ICD-10 classification of } \\
\text { mental and behavioral } \\
\text { disorder: diagnostic }\end{array}$ & Insomnia & $\begin{array}{l}\text { Natural products ( } 36 \% \\
\text { Adults with insomnia; } \\
\text { OR }=3.7 \text { vs. those } \\
\text { without insomnia) } \\
\text { OTC medications ( } 9 \% \text {; } \\
\text { OR }=2.8 \text { vs. those } \\
\text { without insomnia) } \\
\text { Relaxation ( } 38 \% \text { adults } \\
\text { with insomnia; OR =2.6 }\end{array}$ & $\begin{array}{l}\text { Telephone interview } \\
\text { surveys }\end{array}$ & $\begin{array}{l}2001 \\
\text { Being female, being } \\
\text { older (for regular use of } \\
\text { any sleep aid, OTC or } \\
\text { prescription vs } \\
\text { occasional use = mean } \\
\text { age } 52 \text { vs. 43), poorer } \\
\text { self-reported physical } \\
\text { and mental health, }\end{array}$ & 1 \\
\hline
\end{tabular}


Table 1 Research-based studies of self-care for adults for sleep disturbances, 2006-2016 (Continued)

\begin{tabular}{|c|c|c|c|c|c|c|c|}
\hline & Country & $\begin{array}{l}\text { Sleep Assessment Tool/ } \\
\mathrm{s}\end{array}$ & $\begin{array}{l}\text { Condition/ } \\
\text { profile focus }\end{array}$ & $\begin{array}{l}\text { Popular self-care prod- } \\
\text { ucts and practices }\end{array}$ & Method & $\begin{array}{l}\text { Sample/predictors of } \\
\text { use }\end{array}$ & Themes \\
\hline & & criteria for research & & $\begin{array}{l}\text { adults with insomnia } \\
\text { vs. those without } \\
\text { insomnia) }\end{array}$ & & $\begin{array}{l}\text { living in an urban area, } \\
\text { presenting anxiety and } \\
\text { depressive symptoms }\end{array}$ & \\
\hline $\begin{array}{l}\text { Petrov et } \\
\text { al. } 2014\end{array}$ & USA & $\begin{array}{l}\text { Physician diagnosis for } \\
\text { sleep apnea, Berlin } \\
\text { Questionnaire }\end{array}$ & $\begin{array}{l}\text { Stroke and } \\
\text { sleep apnea }\end{array}$ & $\begin{array}{l}\text { OTC sleep medications } \\
\text { (12\% of those using } \\
\text { OTCs were people with } \\
\text { diagnosed sleep apnea } \\
\text { and } 19 \% \text { were those at } \\
\text { high risk of sleep } \\
\text { apnea) }\end{array}$ & $\begin{array}{l}\text { Longitudinal study } \\
\text { involving telephone } \\
\text { interviews and in- } \\
\text { home baseline inter- } \\
\text { views then } 6 \text { monthly } \\
\text { follow up interviews } \\
\text { via telephone }\end{array}$ & $\begin{array}{l}21,678 \\
\text { Being white, being } \\
\text { female, not having left } \\
\text { ventricular hypertrophy, } \\
\text { being high risk for } \\
\text { sleep apnea, non- } \\
\text { smokers, non-diabetics, } \\
\text { higher educational } \\
\text { attainment* } \\
{ }^{*} \text { Not only those with } \\
\text { diagnosed sleep apnea } \\
\text { but those specifically } \\
\text { using OTCs for sleep. }\end{array}$ & 1 \\
\hline $\begin{array}{l}\text { Rosenthal } \\
\text { et al. } 2008\end{array}$ & USA & $\begin{array}{l}\text { Previously physician } \\
\text { diagnosed }\end{array}$ & Insomnia & $\begin{array}{l}\text { OTC medications taken } \\
\text { concurrently with } \\
\text { prescribed medication } \\
\text { (13\% current adults } \\
\text { with insomnia or } \\
\text { previously diagnosed } \\
\text { adults with insomnia). } \\
\text { Herbal medicines (8\% } \\
\text { current adults with } \\
\text { insomnia or previously } \\
\text { diagnosed adults with } \\
\text { insomnia and } 6 \% \text { of } \\
\text { those concurrently } \\
\text { taking prescription } \\
\text { medications). }\end{array}$ & Telephone interviews & 58 & 1 \\
\hline $\begin{array}{l}\text { Sánchez- } \\
\text { Ortuño et } \\
\text { al. } 2009\end{array}$ & Canada & ISI and DBAS & $\begin{array}{l}\text { Insomnia and } \\
\text { insomnia } \\
\text { symptoms }\end{array}$ & $\begin{array}{l}\text { 'Natural' OTC } \\
\text { medications including, } \\
\text { chamomile, valerian, } \\
\text { lemon balm, lavender, } \\
\text { hops, St John's wort } \\
\text { and magnesium. (36\%) }\end{array}$ & $\begin{array}{l}\text { Cross-sectional postal } \\
\text { survey }\end{array}$ & $\begin{array}{l}953 \\
\text { Younger age (mean } \\
\text { age of exclusive natural } \\
\text { product use = } 40 \text { vs } \\
\text { mean age of exclusive } \\
\text { prescription medication } \\
\text { use }=53 \text { ). } \\
\text { Being female, higher } \\
\text { education level* } \\
\text { *these apply to all } \\
\text { those using natural } \\
\text { products for sleep not } \\
\text { just adults with } \\
\text { insomnia }\end{array}$ & 1,3 \\
\hline $\begin{array}{l}\text { Suen et al. } \\
2008\end{array}$ & $\begin{array}{l}\text { Hong } \\
\text { Kong }\end{array}$ & PSQI & $\begin{array}{l}\text { Poor sleep/ } \\
\text { insomnia } \\
\text { symptoms }\end{array}$ & $\begin{array}{l}\text { Poor sleepers more } \\
\text { frequently consumed } \\
\text { milk drinks prior to } \\
\text { sleep than good } \\
\text { sleepers. (Mean } \\
\text { frequency (standard } \\
\text { deviation) and Median } \\
\text { over one week (0-7) } \\
\text { was } 0.67 \text { (1.24), } 0 \text { for } \\
\text { poor sleepers vs. } 0.32 \\
\text { (0.83), } 0 \text { for good } \\
\text { sleepers). } \\
\text { Poor sleepers more } \\
\text { frequently set aside } \\
\text { time for relaxation/ } \\
\text { relaxing exercise prior } \\
\text { to sleep than good } \\
\text { sleepers (mean } \\
\text { frequency (standard } \\
\text { deviation) and Median }\end{array}$ & $\begin{array}{l}\text { Self-administered } \\
\text { questionnaire }\end{array}$ & 400 & 1 \\
\hline
\end{tabular}


Table 1 Research-based studies of self-care for adults for sleep disturbances, 2006-2016 (Continued)

\begin{tabular}{|c|c|c|c|c|c|c|c|}
\hline & Country & $\begin{array}{l}\text { Sleep Assessment Tool/ } \\
\mathrm{s}\end{array}$ & $\begin{array}{l}\text { Condition/ } \\
\text { profile focus }\end{array}$ & $\begin{array}{l}\text { Popular self-care prod- } \\
\text { ucts and practices }\end{array}$ & Method & $\begin{array}{l}\text { Sample/predictors of } \\
\text { use }\end{array}$ & Themes \\
\hline & & & & $\begin{array}{l}\text { over one week }(0-7) \\
\text { was } 0.93(1.52), 0 \text { for } \\
\text { poor sleepers vs. } 0.76 \\
(1.39), 0 \text { for good } \\
\text { sleepers. }\end{array}$ & & & \\
\hline $\begin{array}{l}\text { Vallieries } \\
\text { et al. } 2014\end{array}$ & Canada & $\begin{array}{l}\text { ISI, PSQI, ESS, pre-sleep } \\
\text { arousal scale (PSAS) }\end{array}$ & $\begin{array}{l}\text { Insomnia } \\
\text { symptoms }\end{array}$ & $\begin{array}{l}\text { Insomnia symptoms } \\
\text { contributed } \\
\text { significantly to the use } \\
\text { of prescribed } \\
\text { medication, natural } \\
\text { products for sleep and } \\
\text { OTC medications for } \\
\text { sleep (Wald } X^{2}=11.8 \text {, } \\
10.07 \text {; Wald } X^{2}=5.85 \text {, } \\
\text { all } P<0.02 \\
\text { respectively). }\end{array}$ & $\begin{array}{l}\text { Self-administered } \\
\text { questionnaires }\end{array}$ & $\begin{array}{l}418 \\
\text { Night shift work }\end{array}$ & 1 \\
\hline $\begin{array}{l}\text { Venn and } \\
\text { Arber } \\
\text { et al. } 2012\end{array}$ & England & PSQI & $\begin{array}{l}\text { Poor sleep/ } \\
\text { insomnia } \\
\text { symptoms, } \\
\text { older age }\end{array}$ & $\begin{array}{l}\text { OTC medications } \\
\text { including } \\
\text { antihistamines and } \\
\text { painkillers and herbal } \\
\text { supplements and } \\
\text { prayer (no prevalence } \\
\text { rates) }\end{array}$ & $\begin{array}{l}\text { In-depth semi- } \\
\text { structured interviews }\end{array}$ & 62 & $2,3,4$ \\
\hline $\begin{array}{l}\text { Venn et } \\
\text { al. } 2013\end{array}$ & England & PSQI & $\begin{array}{l}\text { Poor sleep/ } \\
\text { insomnia } \\
\text { symptoms, } \\
\text { older age }\end{array}$ & $\begin{array}{l}\text { OTC medications } \\
\text { including sleep aids e.g. } \\
\text { Nytol, herbal medicine, } \\
\text { antihistamines and } \\
\text { painkillers ( } 39 \% \text { poor } \\
\text { sleepers). } \\
\text { Relaxation techniques. }\end{array}$ & $\begin{array}{l}\text { In-depth semi- } \\
\text { structured interviews }\end{array}$ & $\begin{array}{l}62 \\
\text { Being female }\end{array}$ & $\begin{array}{l}1,2,3 \\
4\end{array}$ \\
\hline $\begin{array}{l}\text { Wahner- } \\
\text { Roedler } \\
\text { et al. } 2007\end{array}$ & USA & $\begin{array}{l}\text { Clinician diagnosis for } \\
\text { Obstructive Sleep } \\
\text { Apnea (OSA) and } \\
\text { apnea-hypopnea index } \\
\text { (AHI) }\end{array}$ & $\begin{array}{l}\text { Obstructive } \\
\text { Sleep Apnea- } \\
\text { Hypopnea Syn- } \\
\text { drome (OSAHS) }\end{array}$ & $\begin{array}{l}\text { Diphenhydramine (7\% } \\
\text { people with } \\
\text { Obstructive-hypopnea } \\
\text { syndrome). }\end{array}$ & $\begin{array}{l}\text { Anonymous survey } \\
\text { questionnaire }\end{array}$ & $\begin{array}{l}406 \\
\text { Being female }\end{array}$ & 1 \\
\hline $\begin{array}{l}\text { Yeung } \\
\text { et al. } 2014\end{array}$ & $\begin{array}{l}\text { Hong } \\
\text { Kong }\end{array}$ & $\begin{array}{l}\text { Chinese version of the } \\
\text { Brief Insomnia } \\
\text { Questionnaire (BIQ) }\end{array}$ & Insomnia & $\begin{array}{l}\text { Western herbal } \\
\text { products (6\% of adults } \\
\text { with insomnia vs. 1\% } \\
\text { good sleepers.). } \\
\text { Physical exercise (6\% } \\
\text { adults with insomnia } \\
\text { vs. } 7 \% \text { good sleepers). } \\
\text { Aromatherapy (3\% } \\
\text { adults with insomnia } \\
\text { vs. } 1 \% \text { good sleepers) } \\
\text { Tai Chi (1\% adults with } \\
\text { insomnia vs. 0\% good } \\
\text { sleepers) } \\
\text { Relaxation (1\% adults } \\
\text { with insomnia vs. 0\% } \\
\text { good sleepers) }\end{array}$ & Telephone survey & 402 & 1,3 \\
\hline
\end{tabular}

et al. 2017; Adams et al. 2013)_enabled methodical evaluation and comparison of the self-care for sleep studies reviewed:

Scores were assigned to the studies separately by two authors; variances in results were resolved through discussion by all authors. Quality scores of individual studies are presented in Table 3.

\section{Results}

A critical review method (Peng et al. 2014; Moore et al. 2017) was used to excerpt, group and review the key findings of the 21 articles. Extracted data were synthesized into three main themes: prevalence of self-care by adults with sleep disturbances; profile, predictors and motivation for the use of self-care by adults with sleep 
Table 2 Description of quality scoring system for the self-care surveys reviewed

\begin{tabular}{|c|c|}
\hline Dimensions of quality assessment & Points awarded ${ }^{\mathrm{a}}$ \\
\hline \multicolumn{2}{|l|}{ Methodology } \\
\hline 1. Representative Sampling Strategy & 1 \\
\hline 2. Sample size $>500$ & 1 \\
\hline 3. Response rate $>75 \%$ & 1 \\
\hline 4. Low recall bias (prospective data collection or retrospective data collection within the past 12 months) & 1 \\
\hline \multicolumn{2}{|l|}{ Reporting of participants characteristics } \\
\hline 5. Classification of specific sleep disturbance reported (e.g. insomnia/sleep apnea). & 1 \\
\hline 6. Age & 1 \\
\hline 7. Ethnicity & 1 \\
\hline 8. Indicator of socioeconomic status (income, education) & 1 \\
\hline 9. Gender & 1 \\
\hline \multicolumn{2}{|l|}{ Reporting of self-care } \\
\hline 10. Definition of self-care products or practices provided to participants & 1 \\
\hline 11. Participants can name self-care products/practices used (open question). & 1 \\
\hline 12. Use of self-care products or practices assessed & 1 \\
\hline
\end{tabular}

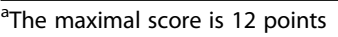

disturbances and Information-seeking, communication with medical providers and self-reported effectiveness of self-care by adults for sleep disturbances.

A vast majority of the articles included in this review focused on adults with ID or IS (Morin et al. 2006; Venn et al. 2013; Liu et al. 2016; Sánchez-Ortuño et al. 2009; Bin et al. 2012; Homsey and O'Connell 2012; Allen et al. 2008; Andrews et al. 2013; Braley et al. 2015; Cheung et al. 2014; Daley et al. 2009; Henry et al. 2013; Krakow et al. 2014; Matthews et al. 2016; Rosenthal et al. 2008;

Table 3 Quality scores of studies on self-care for sleep disturbances

\begin{tabular}{|c|c|c|c|c|}
\hline \multicolumn{5}{|c|}{ Dimensions of quality assessment } \\
\hline Authors/year & Methodology & Reporting of participant characteristics & Reporting of self-care & $\overline{\text { Total score }}$ \\
\hline Allen et al. 2008 & $2(2,4)$ & $3(6,7,9)$ & $2(10,12)$ & 7 \\
\hline Andrews et al. 2013 & $1(4)$ & $1(5)$ & $1(11)$ & 3 \\
\hline Bin et al. 2012 (1) & $3(1,2,4)$ & $4(5,6,8,9)$ & $2(10,12)$ & 9 \\
\hline Braley et al. 2015 & $1(3)$ & $1(5)$ & 0 & 2 \\
\hline Daley et al. 2009 & $2(2,4)$ & $1(5)$ & $3(10,11,12)$ & 6 \\
\hline Henry et al. 2013 & 0 & $1(5)$ & $1(11)$ & 1 \\
\hline Homsey and O'Connell 2012 & 0 & $3(6,8,9)$ & $2(10,12)$ & 5 \\
\hline Krakow et al. 2014 & $3(2,3,4)$ & $5(5,6,7,8,9)$ & 0 & 8 \\
\hline Liu et al. 2016 & $1(2)$ & $4(5,6,8,9)$ & 0 & 5 \\
\hline Morin et al. 2006 & $3(2,4)$ & $4(5,6,8,9)$ & $3(10,11,12)$ & 10 \\
\hline Petrov et al. 2014 & $1(4)$ & $5(5,6,7,8,9)$ & 0 & 6 \\
\hline Rosenthal et al. 2008 & 0 & 0 & 0 & 0 \\
\hline Sánchez-Ortuño et al. 2009 & $2(2,4)$ & $4(5,6,8,9)$ & $3(10,11,12)$ & 10 \\
\hline Suen et al. 2008 & 0 & 0 & $2(10,12)$ & 2 \\
\hline Vallieries et al. 2014 & $1(4)$ & $4(5,6,8,9)$ & 0 & 6 \\
\hline Wahner-Roedler et al. 2007 & $2(3,4)$ & $2(5,9)$ & $3(10,11,12)$ & 7 \\
\hline Yeung et al. 2014 & $1(4)$ & $4(5,6,8,9)$ & $2(10,12)$ & 7 \\
\hline
\end{tabular}

Cheung et al. (2014) (17), Matthews et al. (2016) (73), Venn and Arber (2012), (18) and Venn et al. (2013), (14) were solely qualitative studies and were not assessed via the quality scoring system 
Suen et al. 2008; Vallieres et al. 2014; Venn and Arber 2012; Yeung et al. 2014). Appropriate self-care for ID or IS may be decidedly different for someone with certain symptoms related to, for example, SDB and thus, the few articles that discuss sleep disturbances other than ID or IS-that is those related to SDB (Braley et al. 2015; Petrov et al. 2014; Wahner-Roedler et al. 2007) and RLS (Braley et al. 2015) - are discussed separately in this review. One article that examines the OTC use of different patient groups with either insomnia, RLS or OSA (Braley et al. 2015) will be discussed in both the 'ID or IS', and the 'SDB, RLS and other sleep disturbances' categories, as applicable.

\section{Quality scores \\ ID or IS}

The quality scoring system revealed a breadth of data quality. Four papers were not able to be included in the assessment due to being qualitative papers (Venn et al. 2013; Cheung et al. 2014; Matthews et al. 2016; Venn and Arber 2012), a further four scored two points or under (Braley et al. 2015; Henry et al. 2013; Rosenthal et al. 2008; Suen et al. 2008) demonstrating low methodological quality, and only one paper (Bin et al. 2012) investigating ID or IS employed a representative sampling strategy thus limiting the generalizability of these results. However, more than half of the 19 papers included in the review scored over five points (Morin et al. 2006; Liu et al. 2016; Sánchez-Ortuño et al. 2009; Bin et al. 2012; Homsey and O'Connell 2012.; Allen et al. 2008; Daley et al. 2009; Krakow et al. 2014; Vallieres et al. 2014; Yeung et al. 2014) implying a reasonable level of methodological strength and usefulness across the listed criteria and a third of the papers included used sample sizes of over 500 (Morin et al. 2006; Liu et al. 2016; Sánchez-Ortuño et al. 2009; Bin et al. 2012; Allen et al. 2008; Daley et al. 2009; Krakow et al., 2014) making it possible to determine some useful patterns and themes.

\section{Other sleep disturbances (SDB and RLS)}

Just three papers-all of which investigated use of selfcare for SDB (Braley et al. 2015; Petrov et al. 2014; Wahner-Roedler et al. 2007) and one of which also investigated use of self-care for insomnia (see above) and RLS (Braley et al. 2015)-explored the use of self-care for sleep disturbances other than ID or IS thus making generalizations difficult. However, two of these studies scored over 5 points in the quality scoring system (Petrov et al. 2014; Wahner-Roedler et al. 2007) and one had a large sample size of $>500$ (Petrov et al. 2014) helping to provide a starting point for further research into selfcare for SDB, while a knowledge-base with regards to RLS and self-care needs to be developed.

\section{Prevalence of self-care by adults with ID or IS}

19 out of 21 articles in this review included a focus on ID or IS (Morin et al. 2006; Venn et al. 2013; Liu et al. 2016; Sánchez-Ortuño et al. 2009; Bin et al. 2012; Homsey and O'Connell 2012; Allen et al. 2008; Andrews et al. 2013; Braley et al. 2015; Cheung et al. 2014; Daley et al. 2009; Henry et al. 2013; Krakow et al. 2014; Matthews et al. 2016; Rosenthal et al. 2008; Suen et al. 2008; Vallieres et al. 2014; Venn and Arber 2012; Yeung et al. 2014). While these articles report wide-ranging self-care prevalence rates for sleep disturbances, it is clear from the literature that self-care for ID or IS is common.

OTC use reported by four large studies including $n>$ 500 participants with ID or IS was between 12 and 76\% (mean 35\%, median 27\%) (Liu et al. 2016; Allen et al. 2008; Daley et al. 2009; Krakow et al., 2014) (see Table $1)$. OTC use among people with ID or IS was common although rates of this use specifically to treat ID or IS were between 5 and 49\% (Liu et al. 2016; Allen et al. 2008; Daley et al. 2009; Krakow et al. 2014). Interestingly, one large Canadian study $(n=953)$ found that people with insomnia were twice as likely to use OTCs for sleep as those with only symptoms of insomnia and that both those with ID and IS were more likely to use any OTCs than 'good' sleepers. (Daley et al. 2009).

Other studies included in the review provided more specific descriptions of self-care products than the term 'OTCs' and some also included self-care practices used by adults with ID or IS. Commonly used CAM self-care for ID or IS includes natural products such as herbal medicines (including St John's wort, valerian, lemon balm, hops, kava kava, chamomile, lemon balm, lavender and non-described herbal teas), vitamins, minerals and dietary supplements (including magnesium and melatonin), yoga, self-hypnosis, breathing, warm milk, relaxation, meditation, prayer, deep breathing, guided imagery, PMR, aromatherapy and tai chi. In regards to conventional self-care, the articles selected for review revealed that common treatments for people with ID or IS included OTC hypnotics, antihistamines, diphenhydramine products, diet, exercise, and painkillers.

Comparison between some of the individual types of self-care use reported in the reviewed studies is a challenge due to the different categories of self-care described. However, overall use of self-care by people with ID and IS was high.

All seven studies included in our review which investigated the difference in prevalence rates of selfcare between those with and without ID or IS, found self-care to be higher amongst those with ID or IS than for those without for all reported kinds of selfcare-both conventional and CAM (Morin et al. 2006; Bin et al. 2012; Braley et al. 2015; Daley et al. 2009; Suen et al. 2008; Vallieres et al. 2014; Yeung et al. 
2014) - except physical exercise which was reported to be marginally higher for those without ID than those with ID amongst Hong Kong Chinese in one study of 402 participants (Yeung et al. 2014) although another similar sized study $(n=400)$ from Hong Kong showed poor sleepers more frequently set time aside for relaxation or relaxing exercise before bed (Suen et al. 2008) indicating that is was more relaxing exercise that was used as a strategy.

A nationally representative cross-sectional survey of Australians found herb, vitamin and mineral use to be twice as high amongst people with ID than those without (20\% vs. $10 \%)$ (Bin et al. 2012). Similarly Morin et al. (Morin et al. 2006) identified self-care products and practices (such as natural products $(\mathrm{OR}=3.7)$, OTC medications $(\mathrm{OR}=2.8)$ and relaxation $(\mathrm{OR}=2.6))$ as more likely to be utilized by people with ID than those without ID in a large Canadian study.

Four of the articles included in our review on ID or IS reported prevalence rates of self-care use contemporaneously with conventional prescription medications amongst people with insomnia and symptoms of insomnia (Henry et al. 2013; Rosenthal et al. 2008; Krakow et al., 2014; Andrews et al., 2013) including one large US study of 1210 adults with clinician-diagnosed ID. The study reported that $21 \%$ of adults with ID were concurrently using both OTCs and prescription medications for sleep (Krakow et al., 2014). Amongst the smaller studies included in our review $(n<500)$ the prevalence of the combined use of prescription medications with OTCs ranged from 13 to 73\% (mean 44\% median 46\%) (Henry et al. 2013; Rosenthal et al. 2008; Andrews et al., 2013).

\section{Prevalence of self-care by adults with other sleep disturbances (SDB and RLS)}

Only three of the 21 studies included in our review report the use of self-care for sleep disturbances other than ID and IS (Braley et al. 2015; Petrov et al. 2014; WahnerRoedler et al. 2007). All of these studies included patients with types of SDB (defined in the studies as OSA (Braley et al. 2015), sleep apnea (Petrov et al. 2014) and OSAHS (Wahner-Roedler et al. 2007)). A large American study of 21,678 participants with stroke revealed of those using OTC sleep medications, $11.6 \%$ had sleep apnea and $19.1 \%$ were at high risk of sleep apnea. A smaller study from the U.S.A $(n=406)$ showed the most common OTC product used was Diphenhydramine (Benadryl) (Wahner-Roedler et al. 2007). Another American small sample study also found diphenhydramine-containing products (common non-prescription medications) were used by $40 \%$ of participants with Restless Legs Syndrome (RLS) (Braley et al. 2015). However, the usefulness of this study in regards to self-care use for RLS is limited due to small sample size and because all RLS patients had also been diagnosed with multiple sclerosis (MS). More research with regard to the use of self-care amongst adults with RLS is required.

Unsurprisingly, with limited available research, there were no clear patterns reported for contemporaneous use of self-care and prescription medications for SDB or RLS. One large US study $(n=21,678)$ showed that of those using both prescription and OTC medications, $12 \%$ had diagnosed sleep apnea, and 25\% had a high risk of sleep apnea (Petrov et al. 2014). Given the possible complications with contemporaneous use of prescription and non-prescription medicines, including herbs, it is important for health researchers to investigate this use amongst adults with sleep disturbances such as SDB and RLS further.

\section{Profile, predictors and motivation for the use of self-care by adults with ID and IS}

The predominant socio-demographic predictors of selfcare products and therapy use for ID or IS, in comparison to people who did not engage in self-care for ID or IS, were being female (Morin et al. 2006; Venn et al. 2013; Sánchez-Ortuño et al. 2009; Homsey and O'Connell 2012; Allen et al. 2008; Krakow et al. 2014) having attained a higher level of education or income (Morin et al. 2006; Homsey and O'Connell 2012; Krakow et al. 2014) and being of white ethnicity (Allen et al. 2008; Krakow et al. 2014). The main predictors that were identified for the use of self-care products and practices for ID or IS-being female and having a higher attainment of education or income-are consistent with wider general use of CAM and self-care beyond ID or IS (Bishop and Lewith 2010; Thomson et al. 2012). However, white ethnicity as a predictor is less consistently corroborated by the wider literature with some studies suggesting black, Asian and Hispanic groups may be more frequent users of certain self-care options (Cherniack et al., 2008; Barnes et al. 2004).

Many of the studies included in our review explored motivations for the use of self-care products and practices for ID or IS (Morin et al. 2006; Venn et al. 2013; Cheung et al. 2014; Henry et al. 2013; Matthews et al. 2016; Venn and Arber 2012; Andrews et al., 2013) and some consistent themes emerged. In particular, a commonly reported reason for seeking self-care solutions for ID or IS was as an alternative to conventional front-line medical treatment, because of a concern regarding the safety and long-term efficacy of prescription medications for sleep (Venn et al. 2013; Cheung et al. 2014; Henry et al. 2013; Matthews et al. 2016; Venn and Arber 2012; Andrews et al., 2013). People with ID or IS also had concerns regarding their GP's knowledge of effective treatments or referral pathways that went beyond conventional prescription sleeping medications. The selected studies reported that people with ID or IS often 
believed therefore, their GPs would only be able to help them with short-term medications that they feared or believed would have detrimental side effects. In particular, a fear of addiction to prescribed sleeping pills such as hypnotics was reported amongst adults with ID or IS (Venn et al. 2013; Cheung et al. 2014; Henry et al. 2013; Matthews et al. 2016; Venn and Arber 2012; Andrews et al., 2013). The literature reported that many people with ID or IS perceived that prescription medications for sleep produced unwanted soporific effects the morning after taking them or that they resulted in unsatisfactory, non-restorative sleep (Venn et al. 2013; Cheung et al. 2014; Matthews et al. 2016; Venn and Arber 2012; Andrews et al., 2013). These concerns over conventional medical responses to IS and ID are supported by general literature on insomnia (Stinson et al. 2006; Davy et al. 2015; Cheung et al. 2017). These may be valid reasons for seeking self-care treatments in light of proven side effects of many frontline prescription medications for insomnia (Wang et al. 2014).

The 'immorality' (as an indicator of a lack of selfcontrol because of addiction) of taking prescription or non-'natural' medicines for ID or IS was also reported as a motivator to try out various 'natural' self-help treatments (Venn et al. 2013; Venn and Arber 2012). Interestingly, three papers reported that seeking help for chronic health conditions other than participants' IS was seen as more acceptable; thus, painkillers professionally prescribed for other conditions-or even a partner's conditions-were reported to be misappropriated for the treatment of IS (Venn et al. 2013; Venn and Arber 2012; Andrews et al., 2013).

For older populations, participants interviewed sometimes believed poor sleep was thought to be commensurate with aging, therefore outside the realm of conventional medical treatment (Henry et al. 2013) and believed there was an inevitability about their symptoms which impacted the validity of seeking conventional treatment or wasting GP's time. OTC drugs such as acetaminophen and acetaminophen-diphenhydramine combination drugs were also taken as an inexpensive and dependable alternative to prescription medications for sleep, by adults with insomnia, with fewer side effects (Henry et al. 2013). However, the above motivating factors were reported by studies with small samples and tended to be of low methodological quality and are not highly generalizable, suggesting the need for nationally representative research investigating motivations for self-care use amongst adults with ID and IS.

Another reason identified in the reviewed literature as motivating self-care products and therapy use among people with ID or IS, was a desire amongst such users for a feeling of control and autonomy over their own health-care (Venn et al. 2013; Henry et al. 2013; Venn and Arber 2012; Andrews et al., 2013). One U.S. study on patient responses to insomnia found that $83 \%$ of sufferers sought to treat their insomnia using self-care as a way of 'wresting control' of their lives (Henry et al. 2013). This study also reported that self-treatment of insomnia by study participants would occur both before and after treatment by a sleep specialist and that participants would rather self-treat their insomnia than seek professional treatment, due to a fear of the stigma attached around having insomnia complaints. $38 \%$ of the sample reported feeling stigmatized directly and others (figure not reported) mentioned feeling isolated, weak or abnormal because of their insomnia.

Other studies reviewed reported a perception that some GPs did not consider ID or IS to be a valid complaint (Venn et al. 2013; Cheung et al. 2014; Venn and Arber 2012) and, on the other hand, that persons with ID and IS often did not consider ID or IS as a valid reason themselves to seek help from a medical professional (Venn et al. 2013; Cheung et al. 2014; Venn and Arber 2012).

One large $(n=953)$ Canadian study found chief reasons for seeking natural (CAM-self-care) medications were to treat anxiety and stress and to promote relaxation (Sánchez-Ortuño et al. 2009) suggesting a desire by patients for targeting of the causes for ID and IS rather than insomnia itself, per se and more research regarding these beliefs and motivations is needed.

Profile, predictors and motivation for the use of self-care by adults with other sleep disturbances (SDB and RLS)

One large study $(n=>500)$ investigating a type of SDBsleep apnea-reported that being high risk for the condition was a predictor of self-care (OTC use) (Petrov et al. 2014) and another article reporting a type SDBOSAHS - showed that being female was a predictor (Wahner-Roedler et al. 2007), specifically for the use of the OTC, diphenhydramine. It was also reported that some people with OSAHS engaged in the consumption of OTC medications due to their perception that their GP would not allow them prescription medications for sleep or a fear that their GP would stop their use of existing prescriptions (Wahner-Roedler et al. 2007). There was no information on the profile, predictors and motivations by people with RLS using self-care and more research is clearly required into this topic for SDB, RLS and other types of sleep disturbance.

Information-seeking, communication with medical providers and self-reported effectiveness of self-care by adults with ID or IS

Amongst the four articles included in the review which report on participants' perceptions of effectiveness regarding use of self-care products, findings were varied 
although overall, some satisfaction and belief in efficacy was reported. For example, one study $(n=401)$ found self-care products and practices were considered effective for insomnia by a vast majority of participants who used them including OTCs (100\%), yoga (100\%), exercise (94.7\%), Qigong/Tai chi (66.7\%), relaxation (66.7\%) and western herbal products (66.7\%) (Yeung et al. 2014). Another study $(n=300)$ rated the most successful self-care strategies by participants with IS to be the use of antihistamines, followed by yoga, PMR, deep breathing, taking kava kava, melatonin, guided imagery and taking valerian (Homsey and O'Connell 2012).

Information sources used by people with ID or IS for self-care treatments included pharmacists (Venn et al. 2013; Cheung et al. 2014; Henry et al. 2013), the media and the Internet (Venn et al. 2013; Cheung et al. 2014), television adverts (Henry et al. 2013), books (Henry et al. 2013), friends, family and work colleagues (Venn et al. 2013; Cheung et al. 2014; Henry et al. 2013), herbalists, CAM practitioners at health food stores or yoga centers (Cheung et al. 2014; Venn and Arber 2012) and people's own experience (Venn et al. 2013; Henry et al. 2013) (no percentages were reported for these findings). Interestingly, as reported by one small Australian study, insomnia patients tended not to ask advice of pharmacists because they associated them with pharmacological remedies and only wanted prescription medicines or alternative medicines". However, some participants (no percentages were reported) did indicate they would like to receive more information from pharmacists about the efficacy and appropriate application of CAM medicines to aid sleep (Cheung et al. 2014). Younger adult participants also looked to university counselors for information on potential treatments (Cheung et al. 2014). Men were less likely to report use of external information sources and were sometimes unaware of conventional or CAM self-care options for ID or IS (Venn et al. 2013).

In terms of the communication between medical providers and adults with ID or IS, the reviewed literature found that study participants were often not satisfied with their GPs' knowledge of self-care or alternative options to improve sleep (Venn et al. 2013; Cheung et al. 2014; Henry et al. 2013; Matthews et al. 2016; Venn and Arber 2012; Andrews et al., 2013). People with ID or IS frequently reported feeling frustrated with medical responses to their sleep problems and felt they had unmet healthcare needs (Venn et al. 2013; Bin et al. 2012; Cheung et al. 2014; Henry et al. 2013; Matthews et al. 2016; Venn and Arber 2012; Andrews et al., 2013). A large Australian study $(n=8841)$ found $26 \%$ of people with ID reported an unmet need for health care versus $6.6 \%$ of those without ID (Bin et al. 2012). Failing to be asked about sleep at all or to be listened to and allowed to contribute to a plan for tackling ID or IS with their GP was reported (Venn et al. 2013; Cheung et al. 2014; Matthews et al. 2016; Venn and Arber 2012; Andrews et al., 2013). People with ID or IS also reported assumptions that, or experiences where, GPs would only suggest short-term medications that they considered harmful and that GPs would not or did not have knowledge of viable self-care options to recommend (Venn et al. 2013; Cheung et al. 2014; Henry et al. 2013; Matthews et al. 2016; Venn and Arber 2012; Andrews et al., 2013). Disclosure of the use of self-care products and practices to medical providers was, in turn, not always provided to GPs (Venn et al. 2013; Venn and Arber 2012; Andrews et al., 2013).

The literature also reported that adults with ID or IS also frequently do not disclose their problems with sleep at all to medical providers (Venn et al. 2013; Cheung et al. 2014; Henry et al. 2013; Venn and Arber 2012). One study reviewed reported that only $21 \%$ of people who had IS disclosed these sleep issues with a medical provider (Venn and Arber 2012). All of the male participants in in one small study considered sleep, and the treatment thereof, to be a matter that should not be discussed with any health professional at all (Venn et al. 2013). Therefore, opportunity for the discussion of selfcare treatments for the treatment of ID or IS between medical provider and patient are limited due to this non-disclosure of the sleep issue in the first instance.

\section{Information-seeking, communication with medical providers and self-reported effectiveness of self-care by adults with other sleep disturbances (SDB and RLS)}

There were no articles discussing the informationseeking, communication with medical providers and self-reported effectiveness of self-care by adults with SDB, RLS or other sleep disturbances (apart from ID or IS). In order to understand how patients with sleep disturbances are being informed and what their perceptions regarding self-care are, further research is crucial.

\section{Appraisal outcomes}

Seventeen articles of all 21 articles included in this review were assessed via the quality scoring system. Notwithstanding a reasonable level of design quality demonstrated by many articles included in Table 3 , to date, the overall quality of research design is methodologically limited. For example, as assessed by the quality assessment tool (Table 2) only two articles reported the use of a representative sampling strategy and seven had a sample size of $>500$. Of seventeen articles, only 3 reported response rates of $75 \%$ or higher and ten reported methodologies that involved a low recall bias. 


\section{Discussion}

This paper reports findings from the first comprehensive review of the international literature of self-care use among populations with sleep disturbances. Notwithstanding the high number of papers ineligible for inclusion due to omission of details regarding whether products and practices were self-care or practitioneradministered, two thirds of the empirical studies presented in this paper were published since 2012 - demonstrating a possible growing interest in the use of various types of self-care for sleep disturbances and a growing interest in self-care amongst researchers (Mun et al. 2016).

While the reported use of OTC products for patients with SDB and RLS was high, only two articles for SDB and one for RLS fitted our inclusion criteria. Therefore, further research is required to determine the prevalence of self-care use among these populations. Further, the studies of patients with SDB and RLS that were included in this review only investigated the use of OTC products. While there is literature available on the efficacy of selfcare practices such as purchasing and using compression stockings (Lettieri and Eliasson 2009) for RLS and oral appliances for OSA (Ferguson et al. 2006), there is an absence of research detailing the prevalence and characteristics of this use. Also, while there is evidence to support the use of CPAP machines for improved outcomes in sleep apnea (Marin et al. 2005), patterns of independent use without prescriptions have not been investigated. Further research is required to determine what treatments are being independently sought and implemented by adults with sleep disturbances such as RLS and types of SDB to aid in the development of effective treatments and to guide efficacy research in the future.

The identified high prevalence levels of self-care use for symptoms of ID or IS-necessitates further research. Research regarding the treatment of ID or IS-clinically diagnosed or determined using a validated sleep scale/ index-demonstrated that a wide array of treatments are used. This suggests a lack of consensus amongst people with such sleep disturbances regarding effective approaches and/or resolutions to these conditions. These circumstances are reflected in the wider research evaluating perceived efficacy of treatments for sleeping disturbances such as ID by both individuals with sleep disturbances and those treating them (Everitt et al. 2014; Sivertsen et al. 2010). Further, evidence indicates a lack of confidence by adults with sleep disturbances, in the ability of medical practitioners-or of the prescriptions they might recommend-to cure or improve sleep disturbances over the long term, or to do so without significant harm. Whilst there is some evidence frontline treatments such as benzodiazepines, Dopaminergic agents, zolpidem and zoplicone may have detrimental side effects (Wang et al. 2014; Leach and Page 2015; Gamaldo and Earley 2006), particularly amongst older people (Wang et al. 2014), OTC medications such as antihistamines and analgesics taken without medical advice also have potential for serious harm (Goh et al. 2009; Zhang et al. 2010). This is despite a view by study participants with sleep disturbances such as ID or IS reflected in the reviewed literature that self-care products provide a safer alternative to conventional prescription treatments. There are also concerns by people with ID or IS over the side effects of CAM self-care products which in some cases may have negative effects on people's ability to sleep well (Lichstein et al. 2007) and also have limited evidence for efficacy in the treatment of sleep disturbances (Leach and Page 2015). More detailed research to examine the prevalence of use of specific self-care treatments for persons with various kinds of sleep disturbance is required to identify specific safety issues and concerns and to better aid health professionals with reliable information to guide effective patient care for sleep disturbances.

Evidence summarized in this review suggests selfcare for the treatment of ID or IS is often not disclosed to health professionals which is congruent with literature on self-care disclosure more generally (Chung et al. 2011). As studies included in this review have indicated a high level of OTC use for both ID and IS and some use for other sleep disturbances such as SDB and RLS, future research exploring how self-medication of OTC products may contribute to the risk of harmful drug events is warranted. This is particularly pertinent in light of the high prevalence of concomitant use of prescription and nonprescription medications as identified in our review for ID or IS and for sleep apnea, which could result in harmful drug-herb or drug-drug interactions if not overseen by a qualified health practitioner. The reviewed literature reveals that while many sufferers do not themselves disclose their sleep disturbances, particularly for ID and IS, they do have a desire to be asked about the existence of sleep disturbances by medical professionals and then to be listened to in regards to their treatment preferences. A patientcentered approach, advocated elsewhere (Meredith et al. 2017; Meredith et al. 2019), including collaborative methods of treatment and respectful, open communication between the healthcare professional and patient, may improve the likelihood of patients disclosing their use of self-care (Lichstein et al. 2007). Potential arising from such open communication to circumvent harmful drug interactions will benefit both patients and medical practitioners alike. This approach is particularly pertinent for people with sleep disturbances, whom, as the wider literature shows 
have an increased likelihood of having comorbid illnesses (Meredith et al. 2017; Smagula et al. 2016).

Whilst there were too few studies reporting on selfperceived efficacy of self-care products and practices used for ID or IS (and none for SDB, RLS and other sleep disturbances) to form reliable generalizations, there was a significant level of satisfaction amongst participants for various types of self-care use including yoga, OTC medications (such as antihistamines and acetaminophen), relaxation and deep breathing. While research has shown deep breathing, relaxation and yoga exercises can help alleviate overall sleep quality (Sarris and Byrne 2011; Chien et al. 2015; Orsal et al. 2014) further research is required regarding the prevalence, safety and efficacy of self-care treatments such as OTC medications used frequently for sleep disturbances.; safety concerns for antihistamines in particular have been highlighted (Goh et al. 2009; Zhang et al. 2010). Additionally, in light of suggestions made by research participants that they would like treatment preferences for sleep disturbances such as ID or IS to be discussed collaboratively with their GP, it may be helpful for medical practitioners to ask about the use of-or interest innon-prescription alternatives for ID or IS and other sleep disturbances. Although this review suggests that patients with ID or IS do not generally consider their GP as possessing knowledge of self-care options for sleep disturbances, evidence also suggests that patients frequently do not ask about a GP's knowledge and/or advice about self-care options for the treatment of sleep disturbances (Morin et al. 2006; Stinson et al. 2006). This is also indicated in the wider general literature regarding self-care options- particularly CAM self-care (Thomson et al. 2012; Frawley et al. 2014; Sohl et al. 2015).

Although CAM self-care and conventional self-care for the treatment or improvement of sleep disturbances is being increasingly investigated in the literature and reported prevalence of use of self-care for sleep disturbances is significant, limitations remain in the ability to synthesize results and make reliable generalizations about what self-care is being used and why. First, definitions of self-care are divergent in the literature (Mun et al. 2016). While some papers report and focus on just one aspect of self-care, such as herbal medicines or antihistamines, others blend results with non-self-care types (e.g. conventional medicines including both prescription and non-prescription). Second, comparing studies examining sleep disturbances has been historically challenging due to varying classifications employed (Morin and Espie 2011). For example, definitions of one type of sleep disturbance reviewed in this paper, insomnia, vary immensely in the literature with some studies reporting just one or more of the symptoms of insomnia: difficulty maintaining sleep, difficulty initiating sleep waking up too early, and sometimes, poor quality or non-restorative sleep (Roth 2007) while other studies include diagnostic criteria that includes for example, subjective harm to health or suffering as a consequence of the condition. Others still have applied stricter definitions, for example, The Diagnostic and Statistical Manual of Mental Disorders, Fifth Edition (DSM-5) (Association AP 2013). It has been suggested such discrepancies in the definition of insomnia alone largely account for incongruent estimations of adult insomnia prevalence rates of between 6 to 30\% internationally (Roth 2007).

However, the limitations of these problems have been minimized within this review by including only literature employing a validated sleep index measure or scoring system based on established diagnostic criteria in their methodology, or including participants who had received a clinical diagnosis of a sleep disorder (see Table 1 for sleep assessment tools used in individual studies). While the sleep disturbances and problems being examined differed between many of the studies included in this review, the instruments used to measure the sleep disturbances (which included ID, IS, clinically-measured poor sleep, SWD, OSA and RLS) are visible in the results, allowing for deeper analysis. Likewise, although the parameters of self-care are divergent in the reviewed literature, only papers demonstrating self-care products and practices as distinct from either practitioner-based conventional or CAM medicine, were included in the review. Third, this review is limited to English language publications therefore the omission of non-English materials is likely to introduce a level of bias. Fourth, many of the studies included in the review used small sample sizes and/or were unrepresentative of the general population making it difficult to draw reliable conclusions on many aspects of self-care use. Fifth, this review investigates self-care use across countries with widely varied accessibility to both mainstream health-care and selfcare options.

Despite these limitations, the empirical findings collated in this review do nonetheless suggest a significant use of self-care among people with sleep disturbances. Equally significant is the evidence of the contemporaneous use of self-care products with conventional prescription medications, a finding which is consistent with international literature on self-care use in the broader population (Bishop and Lewith 2010; Chung et al. 2011).

\section{Conclusions}

A significant percentage of people with sleep disturbances such as ID or IS, SDB and RLS appear to utilize self-care practices and products and such use frequently 
appears contemporaneous with conventional prescription medications although research regarding this use is limited for sleep disturbances other than ID or IS. When dealing with patients presenting symptoms of sleep disturbances, medical practitioners such as GPs, need to actively inquire into patients' use of self-care products and practices and into their treatment preferences. This dialogue will enable medical practitioners to advise their patients about the safety and efficacy of self-care products and practices and may also help to avoid harmful drug-drug or drug-herb interactions that may currently be occurring due to a lack of disclosure of concomitant use of self-care and prescription medications by patients to their GPs. Further, GPs should inquire about the existence of symptoms of sleep disturbances amongst patients they may be treating for comorbid conditions as patients frequently do not disclose issues with sleep. Medical professionals may also consider alternative treatment suggestions, in consultation with their patients and according to patient preferences, beyond short-term conventional medical interventions such as hypnotics. In light of both the significant use of, and perceived effectiveness of, many self-care options such as OTCs, herbal products, relaxation, yoga and exercise, health researchers should further investigate both efficacy and safety for self-care options which policy makers could help to distribute this information to both the public and medical professionals.

\section{Supplementary information}

Supplementary information accompanies this paper at https://doi.org/10. 1186/s41606-019-0039-1.

Additional file 1. Search Design.

\begin{abstract}
Abbreviations
AMED: Allied and Alternative Medicine Database; CAM: Complementary and alternative medicine; CINAHL: Cumulative index of nursing and allied health literature; CPAP: Continuous positive airway pressure; DSM-5: The diagnostic and statistical manual of mental disorders, fifth edition; EMBASE: Excerpta medica database; GP: General practitioner; ID: Insomnia disorder; IS: Insomnia symptoms; MEDLINE: Medical literature analysis and retrieval system online; MS: Multiple sclerosis; OSA: Obstructive sleep apnea; OSAHS: Obstructive sleep apnea-hypopnea syndrome; OTC: Over-the-counter; PMR: Progressive muscle relaxation; RLS: Restless legs syndrome; SDB: Sleep Disordered Breathing; SWD: Sleep wake disturbance
\end{abstract}

\section{Acknowledgements}

We thank the Australian Research Council (ARC) for the Discovery Grant that has funded this project (ARC DP140100238), and supported the work of Distinguished Professor Jon Adams for this manuscript through an ARC Professorial Future Fellowship and a ARC PhD scholarship for the lead author of this research, Sophie Meredith - whose research is also supported by an Australian Government Research Training Program Scholarship.

\section{Author contributions}

All authors were involved in conception, design, analysis, interpretation of the data, revision and final approval of this article.

\section{Funding}

None (beyond that mentioned in acknowledgements).

Availability of data and materials

Data sharing is not applicable to this article as no datasets were generated or analyzed during the current study.

\section{Ethics approval and consent to participate}

$\mathrm{N} / \mathrm{A}$.

\section{Consent for publication}

N/A.

\section{Competing interests}

The authors declare that they have no competing interests.

Received: 17 February 2019 Accepted: 12 November 2019

Published online: 07 February 2020

\section{References}

Abraham O, Schleiden L, Albert SM. Over-the-counter medications containing diphenhydramine and doxylamine used by older adults to improve sleep. Int J Clin Pharm. 2017:39(4):808-17.

Adams J, Barbery G, Lui CW. Complementary and alternative medicine use for headache and migraine: a critical review of the literature. Headache. 2013; 53(3):459-73.

Adams J, Prior J, Sibbritt D, Connon I. The use of self-care practices and products by women with chronic illness: a case study of older women with osteoarthritis and osteoporosis. Routledge: Women's Health and Complementary and Integrative Medicine; 2018. p. 89-105.

Allen KD, Renner JB, DeVellis B, Helmick CG, Jordan JM. Racial differences in sleep medication use: a cross-sectional study of the Johnston county osteoarthritis project. Ann Pharmacother. 2008;42(9):1239-46.

Andrews LK, Coviello J, Hurley E, Rose L, Redeker NS. "I'd eat a bucket of nails if you told me it would help me sleep:" perceptions of insomnia and its treatment in patients with stable heart failure. Heart Lung. 2013:42(5):339-45.

American Psychiatric Association. Diagnostic and statistical manual of mental disorders (DSM-5 $\left.{ }^{\circledR}\right)$. Washington, D.C.: American Psychiatric Publishing; 2013.

Backhaus J, Junghanns K, Broocks A, Riemann D, Hohagen F. Test-retest reliability and validity of the Pittsburgh sleep quality index in primary insomnia. J Psychosom Res. 2002;53(3):737-40.

Barnes PM, Powell-Griner E, McFann K, Nahin RL. Complementary and alternative medicine use among adults: United States, 2002. Seminars in Integrative Medicine. Amsterdam: Elsevier; 2004

Bastien $\mathrm{CH}$, Vallières A, Morin CM. Validation of the insomnia severity index as an outcome measure for insomnia research. Sleep Med. 2001;2(4):297-307.

Bertisch SM, Wee CC, Phillips RS, McCarthy EP. Alternative mind-body therapies used by adults with medical conditions. J Psychosom Res. 2009;66(6):511-9.

Bin YS, Marshall NS, Glozier N. The burden of insomnia on individual function and healthcare consumption in Australia. Aust N Z J Public Health. 2012; 36(5):462-8.

Bishop FL, Lewith GT. Who uses CAM? A narrative review of demographic characteristics and health factors associated with CAM use. J Evid Based Complementary Altern Med. 2010;7(1):11-28.

Bishop FL, Rea A, Lewith H, Chan YK, Saville J, Prescott P, et al. Complementary medicine use by men with prostate cancer: a systematic review of prevalence studies. Prostate Cancer Prostatic Dis. 2011;14(1):1-13.

Blay SL, Andreoli SB, Gastal FL. Prevalence of self-reported sleep disturbance among older adults and the association of disturbed sleep with service demand and medical conditions. Int Psychogeriatr. 2008;20(3):582-95.

Boon H, Kachan N, Boecker A. Use of natural health products: how does being "natural" affect choice? Med Decis Mak. 2013:33(2):282-97.

Braley TJ, Segal BM, Chervin RD. Hypnotic use and fatigue in multiple sclerosis. Sleep Med. 2015;16(1):131-7.

Byles JE, Mishra GD, Harris MA. The experience of insomnia among older women. Sleep. 2005;28(8):972-9.

Cherniack EP, Ceron-Fuentes J, Florez H, Sandals L, Rodriguez O, Palacios JC. Influence of race and ethnicity on alternative medicine as a self-treatment preference for common medical conditions in a population of multi-ethnic urban elderly. Complement Ther Clin Pract. 2008;14(2):116-23 8p. 
Cheung J, Bartlett D, Armour C, Saini B, Laba T. To drug or not to drug? A discrete choice experiment exploring patient preferences for managing insomnia. J Sleep Sleep Disord Res. 2017:40(suppl_1):A143-A4.

Cheung JM, Bartlett DJ, Armour CL, Glozier N, Saini B. Insomnia patients' helpseeking experiences. Behav Sleep Med. 2014;12(2):106-22.

Chien HC, Chung YC, Yeh ML, Lee JF. Breathing exercise combined with cognitive behavioural intervention improves sleep quality and heart rate variability in major depression. J Clin Nurs. 2015;24(21-22):3206-14.

Chung VC, Ma PH, Tang TS, Lau CH, Kim JH, Griffiths SM. Do patients tell their clinicians they are using both prescribed and over the counter allopathic and traditional medicines? Eur J Integr Med. 2011;3(4):e289-e98.

Daley M, Morin CM, LeBlanc M, Gregoire JP, Savard J, Baillargeon L. Insomnia and its relationship to health-care utilization, work absenteeism, productivity and accidents. Sleep Med. 2009;10(4):427-38.

Davy Z, Middlemass J, Siriwardena AN. Patients' and clinicians' experiences and perceptions of the primary care management of insomnia: qualitative study. Health Expect. 2015;18(5):1371-83.

Everitt H, McDermott L, Leydon G, Yules H, Baldwin D, Little P. GPs' management strategies for patients with insomnia: a survey and qualitative interview study. Br J Gen Pract. 2014;64(619):e112-e9.

Fejer R, Kyvik KO, Hartvigsen J. The prevalence of neck pain in the world population: a systematic critical review of the literature. Eur Spine J. 2006; 15(6):834-48

Ferguson KA, Cartwright R, Rogers R, Schmidt-Nowara W. Oral appliances for snoring and obstructive sleep apnea: a review. Sleep. 2006;29(2):244-62.

Fernández-San-Martín MI, Masa-Font R, Palacios-Soler L, Sancho-Gómez P, CalbóCaldentey C, Flores-Mateo G. Effectiveness of valerian on insomnia: a metaanalysis of randomized placebo-controlled trials. Sleep Med. 2010;11(6):505-11.

Fouladbakhsh J, Stommel M. Gender, symptom experience, and use of complementary and alternative medicine practices among cancer survivors in the U.S. Cancer population. Oncol Nurs Forum. 2010;37(1):7-15.

Frass M, Strassl RP, Friehs H, Müllner M, Kundi M, Kaye AD. Use and acceptance of complementary and alternative medicine among the general population and medical personnel: a systematic review. Ochsner J. 2012;12(1):45-56.

Frawley J, Adams J, Broom A, Steel A, Gallois C, Sibbritt D. Majority of women are influenced by nonprofessional information sources when deciding to consult a complementary and alternative medicine practitioner during pregnancy. J Altern Complement Med. 2014;20(7):571-7.

Frawley J, Adams J, Steel A, Broom A, Gallois C, Sibbritt D. Women's use and selfprescription of herbal medicine during pregnancy: an examination of 1,835 pregnant women. Womens Health Issues. 2015;25(4):396-402.

Furihata R, Uchiyama M, Takahashi S, Konno C, Suzuki M, Osaki K, et al. Self-help behaviors for sleep and depression: a Japanese nationwide general population survey. J Affect Disord. 2011;130(1-2):75-82.

Gamaldo CE, Earley CJ. Restless legs syndrome: a clinical update. Chest. 2006; 130(5):1596-604.

Goh LY, Vitry Al, Semple SJ, Esterman A, Luszcz MA. Self-medication with overthe-counter drugs and complementary medications in South Australia's elderly population. BMC Complement Altern Med. 2009;9(1):1.

Henry AL, Kyle SD, Bhandari S, Chisholm A, Griffiths CE, Bundy C. Measurement, classification and evaluation of sleep disturbance in psoriasis: a systematic review. PLoS One. 2016;11(6):e0157843.

Henry D, Rosenthal L, Dedrick D, Taylor D. Understanding patient responses to insomnia. Behav Sleep Med. 2013;11(1):40-55

Homsey M, O'Connell K. Use and success of pharmacologic and nonpharmacologic strategies for sleep problems. J Am Acad Nurse Pract. 2012;24(10):612-23.

Innes KE, Selfe TK, Agarwal P. Prevalence of restless legs syndrome in north American and Western European populations: a systematic review. Sleep Med. 2011;12(7):623-34.

Kaufmann CN, Canham SL, Mojtabai R, Gum AM, Dautovich ND, Kohn R, et al. Insomnia and health services utilization in middle-aged and older adults: results from the health and retirement study. J Gerontol A Biol Sci Med Sci. 2013;68(12):1512-7.

Knauert M, Naik S, Gillespie MB, Kryger M. Clinical consequences and economic costs of untreated obstructive sleep apnea syndrome. World J Otorhinolaryngol Head Neck Surg. 2015;1(1):17-27.

Krakow B, Ulibarri VA, Mclver ND. Pharmacotherapeutic failure in a large cohort of patients with insomnia presenting to a sleep medicine center and laboratory: subjective pretest predictions and objective diagnoses. Mayo Clin Proc. 2014;89(12):1608-20.
Leach MJ, Page AT. Herbal medicine for insomnia: a systematic review and metaanalysis. Sleep Med Rev. 2015;24:1-12.

Leger D, Bayon V, Laaban JP, Philip P. Impact of sleep apnea on economics. Sleep Med Rev. 2012;16(5):455-62.

Léger D, Poursain B, Neubauer D, Uchiyama M. An international survey of sleeping problems in the general population. Curr Med Res Opin. 2007;24(1):307-17.

Lettieri CJ, Eliasson AH. Pneumatic compression devices are an effective therapy for restless legs syndrome: a prospective, randomized, double-blinded, shamcontrolled trial. Chest. 2009;135(1):74-80.

Lichstein KL, Payne KL, Soeffing JP, Heith Durrence H, Taylor DJ, Riedel BW, et al. Vitamins and sleep: an exploratory study. Sleep Med. 2007;9(1):27-32.

Liu Y, Zhang J, Lam SP, Yu MWM, Li SX, Zhou J, et al. Help-seeking behaviors for insomnia in Hong Kong Chinese: a community-based study. Sleep Med. 2016;21:106-13.

Marin JM, Carrizo SJ, Vicente E, Agusti AGN. Long-term cardiovascular outcomes in men with obstructive sleep apnoea-hypopnoea with or without treatment with continuous positive airway pressure: an observational study. Lancet. 2005;365(9464):1046-53.

Matthews EE, Signoracci GM, Stearns-Yoder K, Brenner LA. A qualitative study of sleep-wake disturbance among veterans with post-acute moderate to severe traumatic brain injury. J Head Trauma Rehabil. 2016:31(2):126-35.

Meredith S, Frawley J, Adams J, Sibbritt D. The utilization of health services and self-care by older women with sleeping problems: results from a nationally representative sample of 9,110 women. J Aging Health. 2017;30(4):540-58.

Meredith S, Frawley J, Adams J, Sibbritt D. Risk factors for developing comorbid sleeping problems: results of a survey of 1,925 women over 50 with a chronic health condition. J Aging Health. 2019. https://doi.org/10.1177/0898264319832134.

Moloney ME, Konrad TR, Zimmer CR. The medicalization of sleeplessness: a public health concern. Am J Public Health. 2011;101(8):1429-33.

Moore CS, Sibbritt DW, Adams J. A critical review of manual therapy use for headache disorders: prevalence, profiles, motivations, communication and self-reported effectiveness. BMC Neurol. 2017;17(1):61.

Moore TA, Berger AM, Dizona P. Sleep aid use during and following breast cancer adjuvant chemotherapy. Psycho-Oncology. 2011;20(3):321-5.

Morin CM, Drake CL, Harvey AG, Krystal AD, Manber R, Riemann D, et al. Insomnia disorder. Nat Rev Dis Primers. 2015;1:15026.

Morin CM, Espie CA. The Oxford handbook of sleep and sleep disorders. Oxford: Oxford University Press; 2011.

Morin CM, LeBlanc M, Daley M, Gregoire JP, Merette C. Epidemiology of insomnia: prevalence, self-help treatments, consultations, and determinants of help-seeking behaviors. Sleep Med. 2006;7(2):123-30.

Mun S, Park J-H, Baek S-M, Lee M, Choi S-M, Lee S. Self-care use patterns in the UK, US, Australia, and Japan: a multinational web-based survey. Integr Med Res. 2016;5(2):151-60.

Novak M, Mucsi I, Shapiro CM, Rethelyi J, Kopp MS. Increased utilization of health services by insomniacs — an epidemiological perspective. J Psychosom Res. 2004;56(5):527-36.

Ohayon M. Prevalence, diagnosis and treatment of chronic insomnia in the general population. Proceedings of the satellite symposium new developments in the treatment of insomnia-do they really have impact on the primary care settings. 2001.

Ohayon MM. Epidemiology of insomnia: what we know and what we still need to learn. Sleep Med Rev. 2002;6(2):97-111.

Ohayon MM, O'Hara R, Vitiello MV. Epidemiology of restless legs syndrome: a synthesis of the literature. Sleep Med Rev. 2012;16(4):283-95.

Orsal O, Alparslan GB, Ozkaraman A, Sonmez N. The effect of relaxation exercises on quality of sleep among the elderly: holistic nursing practice review copy. Holist Nurs Pract. 2014;28(4):265-74

Pearson NJ, Johnson LL, Nahin RL. Insomnia, trouble sleeping, and complementary and alternative medicine: analysis of the 2002 national health interview survey data. Arch Intern Med. 2006;166(16):1775-82.

Peng W, Adams J, Sibbritt DW, Frawley JE. Critical review of complementary and alternative medicine use in menopause: focus on prevalence, motivation, decision-making, and communication. Menopause. 2014;21(5):536-48.

Petrov ME, Howard VJ, Kleindorfer D, Grandner MA, Molano JR, Howard G. Overthe-counter and prescription sleep medication and incident stroke: the reasons for geographic and racial differences in stroke study. J Stroke Cerebrovasc Dis. 2014;23(8):2110-6.

Qato DM, Alexander GC, Conti RM, Johnson M, Schumm P, Lindau ST. Use of prescription and over-the-counter medications and dietary supplements among older adults in the United States. JAMA. 2008;300(24):2867-78. 
Rosenthal LD, Dolan DC, Taylor DJ, Grieser E. Long-term follow-up of patients with insomnia. Proc (Baylor Univ Med Cent). 2008;21(3):264-5.

Roth T. Insomnia: definition, prevalence, etiology, and consequences. J Clin Sleep Med. 2007;3(5 Suppl):S7.

Sánchez-Ortuño MM, Bélanger L, Ivers H, LeBlanc M, Morin CM. The use of natural products for sleep: a common practice? Sleep Med. 2009;10(9):982-7.

Sandberg JC, Suerken CK, Quandt SA, Altizer KP, Bell RA, Lang W, et al. Selfreported sleep difficulties and self-care strategies among rural older adults. J Evid Based Complementary Altern Med. 2014;19(1):36-42.

Sarris J, Byrne GJ. A systematic review of insomnia and complementary medicine. Sleep Med Rev. 2011;15(2):99-106.

Sarsour K, Kalsekar A, Swindle R, Foley K, Walsh JK. The association between insomnia severity and healthcare and productivity costs in a health plan sample. Sleep. 2011;34(4):443.

Sateia M, Doghramji K, Hauri P, Morin C. Evaluation of chronic insomnia. An American Academy of sleep medicine review. Sleep. 2000;23(2):243-308.

Senaratna CV, Perret IL, Lodge CJ, Lowe AJ, Campbell BE, Matheson MC, et al. Prevalence of obstructive sleep apnea in the general population: a systematic review. Sleep Med Rev. 2017;34:70-81.

Sivertsen B, Krokstad S, Mykletun A, Øverland S. Insomnia symptoms and use of health care services and medications: the HUNT-2 study. Behav Sleep Med. 2009; 7(4):210-22.

Sivertsen B, Nordhus IH, Bjorvatn B, Pallesen S. Sleep problems in general practice: a national survey of assessment and treatment routines of general practitioners in Norway. J Sleep Res. 2010;19(1 Pt 1):36-41.

Smagula SF, Stone KL, Fabio A, Cauley JA. Risk factors for sleep disturbances in older adults: evidence from prospective studies. Sleep Med Rev. 2016;25:21-30.

Sohl SJ, Borowski LA, Kent EE, Smith AW, Oakley-Girvan I, Rothman RL, et al. Cancer survivors' disclosure of complementary health approaches to physicians: the role of patient-centered communication. Cancer. 2015;121(6):900-7.

Stinson $\mathrm{K}$, Tang NK, Harvey AG. Barriers to treatment seeking in primary insomnia in the United Kingdom: a cross-sectional perspective. Sleep. 2006;29(12):1643-6.

Suen LKP, Ellis Hon LK, Tam WWS. Association between sleep behavior and sleep-related factors among university students in Hong Kong. Chronobiol Int. 2008;25(5):760-75

Thomson P, Jones J, Evans JM, Leslie SL. Factors influencing the use of complementary and alternative medicine and whether patients inform their primary care physician. Complement Ther Med. 2012;20(1):45-53.

Tsai Y, Wong TKS, Ku Y. Self-care management of sleep disturbances and risk factors for poor sleep among older residents of Taiwanese nursing homes. J Clin Nurs. 2008;17(9):1219-26 8p.

Vallieres A, Azaiez A, Moreau V, LeBlanc M, Morin CM. Insomnia in shift work. Sleep Med. 2014;15(12):1440-8.

Venn S, Arber S. Understanding older peoples' decisions about the use of sleeping medication: issues of control and autonomy. Sociol Health IIIn. 2012; 34(8):1215-29.

Venn $S$, Meadows R, Arber $S$. Gender differences in approaches to selfmanagement of poor sleep in later life. Soc Sci Med. 2013;79:117-23.

Wahner-Roedler DL, Olson EJ, Narayanan S, Sood R, Hanson AC, Loehrer LL, et al. Gender-specific differences in a patient population with obstructive sleep apnea-hypopnea syndrome. Gender Med. 2007;4(4):329-38.

Wang PS, Bohn RL, Glynn RJ, Mogun H, Avorn J. Hazardous benzodiazepine regimens in the elderly: effects of half-life, dosage, and duration on risk of hip fracture. Am J Psychiatr. 2014;158(6):892-8.

Weaver TE, Maislin G, Dinges DF, Younger J, Cantor C, McCloskey S, et al. Selfefficacy in sleep apnea: instrument development and patient perceptions of obstructive sleep apnea risk, treatment benefit, and volition to use continuous positive airway pressure. Sleep. 2003;26(6):727-32.

Williams PD, Lantican LS, Bader JO, Lerma D. Symptom monitoring, alleviation, and self-care among Mexican Americans during cancer treatment. Clin J Oncol Nurs. 2014;18(5):547-54.

Worthington AD, Melia Y. Rehabilitation is compromised by arousal and sleep disorders: results of a survey of rehabilitation centres. Brain Inj. 2006;20(3): 327-32.

Yeung WF, Chung KF, Yung KP, Ho FYY, Ho LM, Yu YM, et al. The use of conventional and complementary therapies for insomnia among Hong Kong Chinese: a telephone survey. Complement Ther Med. 2014;22(5):894-902.

Zhang D, Tashiro M, Shibuya K, Okamura N, Funaki Y, Yoshikawa T, et al. Next-day residual sedative effect after nighttime administration of an over-the-counter antihistamine sleep aid, diphenhydramine, measured by positron emission tomography. J Clin Psychopharmacol. 2010;30(6):694-701.

\section{Publisher's Note}

Springer Nature remains neutral with regard to jurisdictional claims in published maps and institutional affiliations.

\section{Ready to submit your research? Choose BMC and benefit from:}

- fast, convenient online submission

- thorough peer review by experienced researchers in your field

- rapid publication on acceptance

- support for research data, including large and complex data types

- gold Open Access which fosters wider collaboration and increased citations

- maximum visibility for your research: over $100 \mathrm{M}$ website views per year

At $\mathrm{BMC}$, research is always in progress.

Learn more biomedcentral.com/submissions 